\title{
THE NEGOTIABLE INSTRUMENTS ACT SHOULD NOT BE
}

\section{AMENDED}

\section{Frederick K. Beutei $\dagger$}

From the time the Negotiable Instruments Act was first recommended for adoption it has been the fashion among legal writers to advocate various amendments to and changes in the Act. These suggestions take numerous forms. Some propose to throw out the entire basic theory of negotiable instruments and re-examine the postulates upon which the Act is based. ${ }^{1}$ Others desire only changes in individual sections which range from minute variations in particular verbiage to general alterations of the whole groups of sections. ${ }^{2}$. Still others seek the repeal of important portions of the Act. ${ }^{3}$

In spite of this persistent demand for amendments it is the purpose of this paper to suggest that the N.I.L. should not be amended. The writer does not contend that the Act is theoretically perfect or that at some future time amendments may not be exceedingly useful, but rather that at present any attempt to change the Act itself is ill-timed, inadvisable, and unnecessary. In attempting to do this it will not be either possible or profitable to examine in detail all of the legion of suggested amendments. Since such a discussion is bound to become enmeshed in minute details which obscure the major

$\dagger$ A. B., I92I, Cornell University; LL.B., 1925, S. J.D., I928, Harvard University; Visiting Professor of Law, University of Pennsylvania Law School; Professor of Law, Tulane University; member of Washington and Pennsylvania bars; author of BưsINEsS Problems in the Law of Agency (ig26), Case Problfais and Tests in Business Iaw (1929), editor of Brannan, Negontable INSTRuments LAw (5th ed. in press), and contributor to numerous legal periodicals.

${ }^{1}$ See Francis, Do Some of the Major Postulates of the Lawe of Bills and Noics Noed Re-examination?-(I928) I4 CORN. L. Q. 4I; see also Vernier, Amendments to the Negotiable Instruments Law (I929) 24 ILI. I. REv. I50, I5I-I52, suggesting entire revision of the act.

"Suggested amendments will be found in the following places: BranNan, Necotiasle INSTRUMENTS LAw (Chafee's 4th ed. 1926) pp. v, 69, 80, I02, 286, 3II, 320, 326, 338, 361, $410,420,512,592,599,610,630,645,675,723$ to $725,742,755,830,838,842,884$; Brannan, Some Necessary Amendments to the Negotiable Instruments Law (I913) 26 HARv. L. REv. 493, 494, 500; Britton, Proposed Amendments to the Uniform Negotiable Instruments Law (1928) 22 ILL. L. REv. 815; Dickinson, Amending our Negotiable Instruments Law (1928) 34 W. VA. L. Q. 326; Puttkammer, Further Amendments to the Negotiable Instruments Law (I928) 23 ILL. L. Rev. 73; Turner, Factual Analysis of Certain Proposed Amendments to the Negotiable Instruments Laze (I929) 38 Y ALE L. J. I047; Turner, Revision of the Negotiable Instruments Law (I928) 38 Y ALE L. J. 25; Vernier, Amendments to the Negotiable Instruments Law (I929) 24 ILL. L. REv. I50, and numerous authorities there cited.

${ }^{3}$ Repeal of $\S \S 40$ and 47 has been recommended by committees of the conference, see HaNDBOOK OF THE National. CONFERENCE OF CoMImissioners on Uniform State Laws (1928) 185: Program of tae National Conference of Commissioners on Uniform State LAwS (I93I) 29; Professor Brannan's suggestion for amendment to sections II9 and I20 removes the law of suretyship from the act, see BRANNAN, NEGOTIABLE INSTRUMENTS LAw, 725 et seq. See also Hening, The Uniform Negotiable Instruments Law (IgII) 59 U. of PA. L. REv. 47I, 532, suggesting repeal of $\$$ I4, 62; AMES, THE NEgotTABLE INSTRUMENTS LAW (1900) I4 HARV. L. REV. 24I, 244 et seq. recommending repeal of $\$ \S 3$ (2), and I37, IIg (4), I20 (3), (5) and (6). 
principles involved, this paper will devote itself to the motives, purposes and theories behind the proposed amendments and will attempt to show that they are not in accord with the major policies of uniform legislation.

The Theories and Purposes Behind the N.I.L.

Before discussing the proposed amendments it might be well to recapitulate briefly the reasons why the Negotiable Instruments Act came into existence.

One should keep clearly in mind that at the time the Uniform Laws Commission was started there was a complete breakdown in the common law of negotiable instruments. The decisions in the various states were in irreconcilable conflict and many of the established doctrines of the law were out of line with commercial practice. ${ }^{4}$ This condition constituted such a burden upon commerce that the Anierican Bar Association felt itself driven to the necessity of drafting uniform laws. ${ }^{.}$

The Negotiable Instruments Act was the first of a series of attempts to alleviate the difficulties growing out of the conflicting decisions by reducing the commercial law to a written code. The objectives to be attained were certainty of rule of law, achievement of uniformity by removal of conflicting decisions, alignment of law with new commercial practices, and the creation of a new legal basis upon which courts, jurists and business men could rely. ${ }^{6}$

The success of such a project necessarily involved scrapping of great quantities of the conflicting common law of various jurisdictions, the repeal of numerous local statutes and a change in some of the basic common law theories of negotiability. ${ }^{7}$ Out of this effort it was hoped that harmony in the decisions and a uniform commercial practice would result. Unfortunately, the courts have not immediately fallen in line with the purpose of the Act and many conflicting decisions are still to be overruled. ${ }^{8}$ This temporary failure to achieve uniformity has carried with it a certain disillusionment,

- See Ogden, Negotiable Instruments (3d ed. I93I) IO; Jones, Uniformity of Laws through National and Interstate Codification (1894) 7 VA. B. A. REP. I57, I62 et seq., rethrough National and Interstate Codification (1894) 7 Vart (1894) II BANKING L. J. I37; 'Lapp, Uniform State Legislation (I910) 4 printed in part (1894) II BANKING The Necessity for Uniformity in the Laws Governing AMr. PoL. SCr. REv. 576; Tompkins, The Necessity for Unial Paper (1890) I3 A. B. A. REP. 247; Wheeler, The Necessity for Uniform Laws Governing Commercial Paper in the United States (1896) 13 BAN KING L. J. 694.

- Snyder, The Problem of Uniform Legislation in the United States (I892) I5 A. B. A. REP. 287, 307 to 309 ; see Report of Committee on Uniform State Laws (I89I) I4 A. B. A. REP. 365 , and material there cited; and see the excellent discussion by Eaton, Uniformity in Judicial Decisions Arising under the Negotiable Instruments Act (IgI3) I2 MICE. L. Rev. 89.

- Brewster, The Promotion of Uniform Legislation (I897) 6 YALE L. J. I32; Uniformity of State Laws (I9II) 23 GREen BAG 6.53 .

${ }^{2}$ For a number of these changes for the better see Ames, op. cit. supra note 3, at 24I, 242-244; Chafee, in Bransan, op. cit. sitpra note 2 , at vii, viii.

8 The seriousness of this attitude of the courts is discussed in detail in another article, see Beutel, Necessity of a New Technique in Interpreting the N.I.L. (I93I) 6 TULANE I. REV. I. 
and has become a starting point for numerous suggestions for amendment to the Act. ${ }^{9}$

\section{Disputes on What and How to Codify}

Even before the Act was adopted in many jurisdictions, disputes arose among the authorities on what and how to codify. Some experts disagreed with the Commission on which of the conflicting rules of law should have been adopted to cover particular cases. Often the critics preferred a rule which the Commission had rejected instead of the one actually adopted. Dean Ames' suggested amendments to sections 9-3, 20, 40, 65, 66, 70, I I9-4, I75 and $186,{ }^{10}$ are illustrations of this point of view.

Others agreed with the rules of law but disagreed with the Commission on how to codify, preferring one manner of statement of the law rather than another, though both reached substantially the same result. Numerous changes of this type have been advocated. ${ }^{11}$ One of the best examples is Professor Williston's suggested amendment to section 23, which reads as follows :

"Where the signature of a person is forged or made without authority it is inoperative to render him liable or to transfer his rights under the instrument unless he is precluded from setting up the forgery or want of authority." 12

Whereas the original Act reads:

"When a signature is forged or made without the authority of the person whose signature it purports to be, it is wholly inoperative, and no right to retain the instrument, or to give a discharge thereof, or to enforce payment thereof against any party thereto, can be acquired through or under such signature, unless the party against whom it is sought to enforce such right is precluded from setting up the forgery or want of authority." 13

The Williston amendment has been justified on the grounds that it would make the forger liable as an indorser ${ }^{14}$ or personally liable on the instru-

- For example, see Hening, op. cit. supra note 3, at 471, 532 .

${ }^{10}$ Ames, op. cit. supra note 3 , at $24 \mathrm{I}, 246$ et seq.

"Dean Ames himself places most of his own objections in this category, see ibid. 244, and see also Vernier, op. cit. subra note 2 , at 157 et seq.

${ }^{22}$ See Handbook of Nat. Conf. of Comm'rs on Uniform State Laws (1928) 183; ibid. (1927) 624. The italics indicate the amendment.

${ }^{\text {is }} C f$. the latest proposed amendment, which reads as follows:

"When a signature is forged or made without the authority of the person whose signature it purports to be, and no right to retain the instrument, or to give a discharge thereof, or to enforce payment thereof against any party thereto, can be acquired through or under such signature, unless the party against whom it is sought to enforce such right is precluded from setting up the forgery or want of authority."

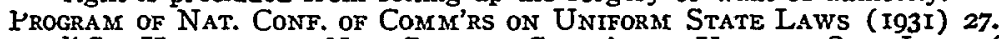

is See HandBook of Nat. Conf. OF CoMm'rs on Uniform Sate Laws (1927) 630; ibid. (1928) I91. The draftsman evidently overlooked the fact that so far as the forgery of the maker's signature is concerned the result he desires is now reached by $\S 65$, and could also be achieved on analogy to this section in the case of the forged indorsement. 
ment, ${ }^{15}$ overlooking section $I 8$, which provides that, with certain exceptions, of which this is not one, no person is liable on the instrument unless his signature appears thereon. ${ }^{16}$

A third group of suggested amendments grows out of a fundamental disagreement with the Commission on the policy of codification. The Commission chose the policy of codifying the entire law of negotiability. The critics desired only partial codification. Thus, many authorities, led by Professor Chafee, took the position that the Act should not attempt to codify all of the law of negotiable instruments, but should follow the British Act in including only the law of notes, checks and drafts and leaving out other types of commercial paper. ${ }^{17}$ These authorities attempted to argue that this was the proper interpretation of the Act ${ }^{18}$ in spite of the broad wording of Article I, which seems clearly to include all types of negotiable instruments. When the courts followed the literal meaning of the Act ${ }^{19}$ and gave it the broad interpretation, numerous amendments were immediately suggested. ${ }^{20}$

The first of these three types of objections involved simply a choice between two rules of law, both of which have some semblance of justice and judicial support. ${ }^{21}$ Since one has been chosen, as a matter of policy it should not be disturbed unless great hardship on the parties involved or some major business dislocation has resulted. In the absence of such facts, which as yet have not been presented, the rule of.law chosen should not be changed, and this type of amendment is worthless.

The second type of suggested amendments, growing out of a disagreement on how to express the rule of law, is also unnecessary. If the rule of law intended by the Commission can be determined from the statute, the precise wording is of no great importance, especially in absence of proof that the amendment is clearly better than the original. The fact that such amendments are not substantial improvements is shown by the complete disagree-

\footnotetext{
${ }^{\text {Is }}$ Slightly different reasons are given by the latest committee, see Program of Nat. CoNF. of COMM'RS ON UNIFORM STATE LAWS (I93I) $4 \mathrm{I}$; note also the changes in wording of footnote 13 supra.

${ }^{10}$ Many of the other amendments suggested by Professor Williston's committee are of an equally trivial nature, see the proposed amendments to $\$ \$ 6,16,52,53,70$, I10, 160 , and 186 , HANDBOOK OF NAT. CONF. OF CoMm'rs on UNIFORMi STATE LAws (Ig28) I82 et seq., and many of these and similar amendments retained in the present committee's recommendations; see Program of Nat. Conf. of Commi'rs on Uniforar State Laws (ig3i) 25 et seq.

${ }^{17}$ See BranNaN, op. cit. supra note 2 , at 5 et seq.

${ }^{28}$ Ibid. 7 .

${ }^{10}$ See Brannan, Negotiable Instruments Law (Beutel's 5th ed. in press) § I "In General" and cases there cited.

>0 The amendments to $\S \S I, 5,6$ of the act as proposed by Professor Williston's committee are inserted for this purpose; see HaNDBOOK of NAT. CONF. OF CoMra'RS ON UNIForar STATE LAwS ( 1928 ) I90; so also the amendments to $\$ \S I, 2,3,4$ and 5 proposed by the present committee, see Program of NAT. CONF. OF COMM'RS ON UNIFORM STATE LAwS (I93I) 37 et seq.; Vernier, op. cit. supra note 2, at 150, 153, and authorities there cited; cf. (1918) 6 CAI. L. Rev. 444, 448; Note (1930) 40 YaLE L. J. 26 I.

${ }^{21}$ See Brewster, Uniform State Laws (1898) 21 A. B. A. REP. 315, 322.
} 
ment among those suggesting changes of this sort on the particular words to be used. ${ }^{22}$

The third objection, that the Commission adopted too broad a policy of codification, seems also to be untenable. It must be kept in mind that the common law has failed and is still failing properly to solve these commercial problems. Codification has been the only remedy; therefore, broad codification, unless it is working irreparable hardships, is to be preferred to the narrow type of statute because it removes more of the difficulties from the common law.

The objection that broad codification is causing rigidity and restricting the development of the law will be dealt with later.

\section{Partial Codification}

Many of the difficulties attributed to the N.I.L. are due to the fact that it is necessarily a partial codification. When the Commission on Uniform Laws undertook to codify the law of negctiable instruments it was faced immediately with a very complicated problem. It is a truism that every field or subject in the law touches upon every other field or subject. So close is this contact that it was impossible to codify the law of bills and notes without including or touching upon questions of contracts, agency, corporations and many other branches of the law. How much to codify, then, becomes a diffcult problem; the sort of problem to which there is no satisfactory answer. Probably no two persons would draw the line at the same place, and no matter what particular subjects were included or left out trouble would surely follow.

Where the legal structure of a people contains within itself two different types of law springing from different theories as to the nature of law and requiring different methods of interpretation and application to a given set of facts, it is not surprising that conflicts should develop along the border line. Many of the gravest difficulties arising under the N.I.L. are due to this inevitable conflict between common law and written law. Where shall the statute be extended in derogation of the common law, and where shall the common law be extended to limit the statute? The answers to these questions have caused much trouble in problems involving agency, ${ }^{23}$ capacity, ${ }^{24}$ illegality, ${ }^{25}$ suretyship and many other subjects with an increasing flood of suggested amendments.

${ }^{2}$ Cf. Dean Ames' suggestions, op. cit. supra note 3, at 244 et seq.; Williston's suggestions, HANDBOOK OF NAT. CONF. OF COMM'RS ON UNIFORM STATE LAWS (I928) I80 et seq.; Britton, op. cit. supra note 2, at 815; Vernier, op. cit. supra note 2, at 150 ; Turner, Revision of the Negotiable Instruments Law (1928) 38 Y ALE L. J. 25; the proposals of the present committee, Program of Nat. Conf. of Comm'rs on Uniform State Laws (I931) 22; see also supra note 20.

${ }_{2}$ See Beutel, The Liabilily of an Unauthorized Agent on an Instrument Signed in the Name of His Principal (I93I) 5 TULANE L. REv. 28I.

$\approx$ See BRANNAN, op. cit. supra note 2 , at 179 to 182,546 to 548 ; see suggested amendments Vernier, op. cit. supra note 2, at I 50 , I58.

${ }^{2}$ Note the unsatisfactory condition of the cases under $\S 55$, BRANNAN, op. cit. supra note 2 , at $4 \mathrm{Ig}$ to 420,428 to $44 \mathrm{I}$, and the suggestions for revival of real defenses by amendment; Hening, op. cit. sutpra note 3 , at $47 \mathrm{I}, 49 \mathrm{I}$ et seq.; Vernier, op. cit. supra note 2 , at $150,162$. 
Most of the amendments offered at the last meeting of the Commission on Uniform Laws, to the title of the Act and sections I, 2, and $5,{ }^{26}$ are simply a retreat from the position taken by the original Act that the entire law of negotiability should be codified. These amendments, like Professor Brannan's suggested amendments to sections IIg and Izo deleting the law of suretyship from the Act, ${ }^{2 \pi}$ are not particularly helpful because they simply throw vexatious problems out of the law covered by the Act and back into the common law where they would again become subject to the unsatisfactory conflicts which caused the original enactment of the code. ${ }^{28} \mathrm{New}$ conflicts also would be certain to develop along the new border line thus created between common law and written law. This policy of amendment, carried to its logical conclusion, would amount to the ultimate repeal of the Act with the reappearance of the intolerable conditions which it was enacted to prevent.

Failure to Appreciate the Nature of Codified Law and Its Relation to Court Decisions

Many of the suggested amendments have grown out of a failure to appreciate the nature of codified law. We have become so accustomed to speak of a court decision as the "law on the point" that we often fail to realize that when the common law is reduced to a code a radical change takes place in the form of the law and the function of the court decision. When the law is codified it is no longer to be found in the decisions and the ratio decidendi flowing therefrom. A code statute unlike the ordinary statute familiar to the common-law lawyer is not an exception to the law to be narrowly construed. It contains within itself an embodiment of the law on the subject which it covers. Therefore its words are to be given a broad meaning rather than a strict construction, and when the plain meaning of the words does not cover a point then they are to be used as examples of principles of law which are deduced from the code itself and not from previous cases.

In this state of the law it is clear that the court decisions under the N.I.L. are not law but are mere applications of the law to certain sets of facts and as such must necessarily lose much of their former force. After a case is decided the law is still found in the code and not in the cases. ${ }^{29}$ If the court has, either by error or intention, decided a case contrary to the plain meaning or proper interpretation of the statute the law has not been changed and amendments are unnecessary. This is especially true in those instances where the courts ignore the N.I.L. or twist its meaning to suit their own

${ }^{29}$ See Program of Nat. Conf. of Comm'rs on Uniform State Laws (I93I) 22 to 24 , 37 to 38 .

"See Brannan, op. cit. supra note 2 , at 720 to 725 .

${ }^{23}$ See Turner's criticism to this effect in (1028) 38 YALE L. J. at 47 et seq.

${ }^{2}$ Cf. Frank, Are Judges Human? (I93r) 80 U. of PA. L. Rev. I7, 223. 
ideas of justice in a particular case. ${ }^{30}$ This deity complex on the part of some courts which causes them to decide cases on their own "judicial hunch" in the teeth of the plain meaning of statutes has been condemned by much abler writers. It is sufficient to say here that the cure for such difficulties, in so far as they affect the N.I.L., does not lie in amendments to the Act; the argument is to the court and not to the legislature. Where there is a basic codified law, erroneous court decisions merely misapply and do not misstate or change the law. This principle is well recognized by the courts themselves and it is not uncommon to find them reversing previous decisions on the ground that they were based upon unsound interpretation or contrary to the weight of authority under the Act.

In light of these principles, amendments which have as their sole purpose removing conflicting decisions such as those on the question of the payee as a holder in due course, ${ }^{31}$ the effect of "as per contract" on negotiability and the like are unnecessary. ${ }^{32}$ If the proper intent of the Act is clear or can be ascertained by the application of sound principles of statutory interpretation the courts themselves soon rectify the difficulties. ${ }^{33}$ As a practical matter it should be noted also that it is much easier to get a court to reverse itself than to have an amendment passed by over fifty legislative bodies.

\section{Hostile Interpretation, Ignoring Established Rules of Statutory Construction}

One very fruitful source of unnecessary amendments has been a certain hostility to the Act as shown in the failure of critics and courts alike to apply well established rules of statutory interpretation. There is a sort of distrust of written law on the part of common law lawyers and writers and a tendency to glorify the common law. The usual excuse given is that statutes are the rigid work of bungling legislators while the common law is the embodiment of principles of justice and right. Statutes are expected to be poorly drawn while court decisions are the work of experts. This attitude has had a marked influence on the articles and comments written in the field of bills and notes since the enactment of the N.I.L. Most of the scholars approach the

\footnotetext{
${ }^{30}$ For a summary of this tendency and extent to which it has been carried, see Beutel, op. cit. supra note 8 .

31 For example, see suggested amendments to $\$ \S 16,30$ and 52, Program of Nat. Conf. of Comm'rs on UNIForm STATE Laws (I93I) 26 to 29,40 to 43 ; and HaNDBook of Nat. CONF. OF COMM'RS ON UNIFORM STATE LAWS (I928) 183, 184, I85, I91. I92.

${ }^{32}$ See (I929) 4 TUtaA NE L. Rev. 126.

${ }^{33}$ It should be noted that on the question of payee as a holder in due course alone the courts of six states changed their position between I924 and 1930. Washington courts flatly overruled previous contrardecisions to hold the payee a holder in due course, while the courts in Iowa, Kentucky, Oklahoma and North Carolina changed their position in this direction by deciding cases irreconcilable with previous decisions to the contrary. Texas courts on the other hand seem to have reversed their former affirmative stand. $C f$. BranNan, Negotiable INSTRUMENTS LAw (Beutel's 5th ed. in press) $\$ 52$, "Payee as a holder in due course", with ibid. (Chafee's 4 th ed.) 261 to 369 . This tendency will be examined at length in a later paper.
} 
Act on a sort of defect hunt. They take great delight in exposing apparent defects. Under this critical treatment every possible ambiguity is likely to develop into a conflict between sections, a hiatus in the Act, or a bungling bit of codification which has failed properly to state the law. Having thus exposed the inadequacies of the Act the critic is enabled to retire into the realm of pure and undefined common law to work out the principles of the justice involved in his particular problem. When these have been discovered in the common law, or the critics idealization thereof, amendments to correct the Act are usually forthcoming.

This approach to the N.I.L. overlooks the fundamental facts that it is the product of the most expert organ of legislation yet assembled in this country, ${ }^{34}$ and the basic fact that the common law in this field at least, far from being in the ideal state usually pictured, was in such a state of collapse that codification was forced upon an unwilling bench and bar by the sheer weight of necessity.

When the simplest principles of statutory construction are applied to the Act some of the suggested amendments, which have been seriously advocated by men entitled to the greatest respect, are open to the charge of ill considered and hasty draftsmanship. For example, it is a well-settled rule of statutory construction that a statute must be read as a whole to determine its meaning. Ambiguities or omissions in the subject matter of one part of the Act are to be supplied by references to other sections. ${ }^{35}$ Yet in spite of this rule the Commission on Uniform Laws has had before it for consideration the following amendment to section $52::^{36}$ "A holder in due course is a payee or other holder who has taken the instrument . . ." when section I9I of the present Act provides: "Holder means payee . . ." Many other equally futile amendments have been proposed. ${ }^{37}$

st See MacChesney, Uniform State Laws (I9I6) ILL. State B. A. REP. 399, 430 et seq.; What the Commissioners on Uniform Laws are Doing for the People of the United States (I912) 75 CENT. L. J. I. This number contains other interesting articles and material about the work of the Conference.

${ }^{3}$ Black, Interpretation of Statutes (2d ed. I9II) 23, 242; see also DWarris, ConStruction of Statutes (Potter's ed. I885) I28 citing Vattel, 136 citing Rutherford, I40 citing Domat, 144 the so-called American Rules, I2.

${ }^{23}$ The section now reads: "A holder in due course is a holder who has taken the instrument. . . " See Mr. Brannan's able comment, BrannaN, op. cit. supra note 2, at 123 et seq.

${ }^{37}$ The Conference Committee in 1928 proposed the following amendment to \& IIo; "Where a waiver of presentment, protest or dishonor is embodied in the instrument it is binding upon all parties . . " adding presentment, protest or dishonor to the general term waiver in spite of the fact that these matters were already covered by $\$ \$ 82$ (3), III and I59; cf. also $\$ 5$ (3).

The same committee also recommended that $\$ 160$ be changed as follows: "When an instrument is lost or destroyed or wrongly detained from the person entitled to hold it, protest may be made on a copy or written particulars thereof" substituting "instrument" for bill, but such a change was not necessary in light of $\$ \S I 18$, 129 and 152 . 
So also it is elementary that sections of the same statute should never be given conflicting meanings where they can be reconciled. ${ }^{38}$ But in spite of this simple rule of common sense in statutory interpretation there has been talk of conflict between sections 9 (5) and $40^{39}$ with the seriously considered repeal of section $40 ;^{40}$ this, regardless of the fact that one of the framers of the Act almost thirty years ago, pointed out the true meaning of these sections ${ }^{41}$ which has now been adopted by the Commission ${ }^{42}$ and seems to have been the business understanding of the law merchant from the beginning. ${ }^{43}$

It should be noted here that it is to the credit of the Commission that the progress of amendments of this sort has been exceedingly slow. It is also either a great credit to the N.I.L., or a discredit to its opponents, that it has weathered this sort of adverse criticism with only thirty-one suggested amendments approved for preliminary considerations by the Committee of the Conference. ${ }^{44}$

Fortunately, many courts have refused to adopt a hostile attitude towards the Act and some of the greatest difficulties found in the sections by the writers and suggestors of amendments are being satisfactorily ironed out by reference to other sections of the Act. A few examples will show the possibilities of the trend of judicial interpretation in this direction. The alleged difficulty with section 29 , which seems to give a holder for value not a holder in due course greater rights against an accommodation maker than he would have against an ordinary maker ${ }^{4 \overline{5}}$ has been satisfactorily cured in a decision of the Court of Appeals of California ${ }^{46}$ by reference to sections

So also the same committee suggested changing $\S$ I 86 adding, "and notice of dishonor must be given to the drawer as provided in the case of bills of exchange" when the present act provides, $\S 185$ "Except as herein otherwise provided the provisions of this act applicable to a bill of exchange payable on demand apply to a check"; and see $\S 6 \mathrm{r}$. This is apparently an inartistic method of meeting Dean Ames' criticism of this section, see op. cit. supra note 3, at 256. Dean Ames' second criticism of $\$ 49$, see ibid. 250, arises from this same sort of perversity. To reach his conclusion one must interpolate "only" into $\S 49$ and ignore $\$ \S 29$, $5 \mathrm{I}$ and $\mathrm{IgI}$.

${ }^{33}$ BLACK, op. cit. silpra note 35 , at 322, 325; DWARRIs, op. cit. subra note 35 , at 132 citing Puffendorf, 144 American Rules, 5 and 12. cited.

${ }^{30}$ See Brannan, op. cit. supra note 2, at I02, 294, 326 and numerous authorities there

* See Hankbook of Nat. Conf. of Comm'rs on Uniform State Laws (ig28) i85, igz.

4U Under this interpretation section 40 applies only to an instrument originally payable to bearer while the case of an instrument payable to order and indorsed in blank is governed by $\$ \$ 9$ (5) and 34. Eaton, The Negotiable Instruments Lavo (I904) 2 MICH. L. REV, 260, 274.

2 See the report of the committee on amendments, Program of Nat. Conf. of Comar'ss of UNIFORM STATE LAWS (I93I) I9.

"3ee Turner, A Factual Analysis of Certain Proposed Amendments to the Negotiable Instruments Law (I929) 38 Y AIE L. J. I050 et seq.; see also supra notes $4 \mathrm{I}$ and 42.

" See Program of Nat. Conf. of Comm'rs on Uniform State Laws (I93I) 22 to 37.

¿s See Brannan, op. cit. supra note 2 , at 286 et seq., and authorities there cited.

${ }^{46}$ Pacific Southwest Trust and Savings Bank v. Valley Finance Corp., 99 Cal. App. 728, 279 Pac. 222 (1929), rehearing denied 280 Pac. I34 (1929). 
$16,{ }^{47} 52^{43}$ and $5^{89}$ which sections seem clearly to make the above result impossible, and such is now the great weight of authority. ${ }^{50}$

So also the problem of the liability, under section 20 , of an unauthorized agent who signs his principal's name to an instrument, which has caused so much discussion among the writers, ${ }^{51}$ has been successfully solved by Judge Cardozo in New Georgia Bank v. Lippman ${ }^{52}$ by reference to the expressed intent of the framers and to the social desirability of the result. ${ }^{.53}$

If writers in the field had used half the ingenuity in finding sensible solutions of problems within the N.I.L. that they have exerted in limiting its scope and exposing its defects, it is submitted that the group of suggested amendments would now be decreased by at least two-thirds, the science of obtaining justice under written law in America would be much further advanced, and the state of the decisions would be in a far more satisfactory condition.

\section{Pressure of Organized Interests Behind Amendments}

Though the most obvious source of suggested amendments to the Act has been the writings of legal scholars, it is by no means the only source. The influence of organized interests, which are affected by the Act, is also an important factor to be reckoned with. Proposed amendments coming from this source should be subjected to more careful scrutiny than any others because they approach the problems from a certain self-interested bias. Although it seldom comes to light in the form of direct publicity or articles in law reviews, ${ }^{54}$ anyone closely connected with the Uniform Laws Commission or any legislative body will testify that the bankers, brokers, exporters and trade associations exert a constant and powerful influence, even in the draft-

$n$ "As between immediate parties and as regards a remote party other than a holder in due course .. . the delivery may be shown to have been ... for a special purpose only."

is " A holder in due course is a holder who has taken the instrument under the following conditions: . . .

(2) That he become a holder before it was overdue. . . .

(4) That . . he had no notice of infirmity in the instrument or defect of title of the person negotiating it."

See also $\$ 55$ defining a negotiation in breach of faith as a defect of title.

49 "In the hands of any holder other than a holder in due course, a negotiable instrument is subject to the same defenses as if it were non-negotiable."

to Rylee v. Wilkerson, I34 Miss. 663, 99 So. 901 (I924) ; Weiser Nat. Bank v. Peters, 174 Ark. 984, 298 S. W. 878 (I927); Bartels v. Suter, I30 Okla. 7, 266 Pac. 753 (I928); Wilhoit v. Seavall, I2I Kan. 239, 246 Pac. Ior3 (I926), Note (I927) 48 A. I. R. I273, I280; Dittmeir Real Estate Co. v. Knox, 259 S. W. 835 (Mo. App. I924) ; Comimky v. Coleman II4 N. Y. Supp. 875 (Ig09); Comstock v. Buckley, I4I Wis. 228, I24 N. W. 4I4 (I9I0); cf. Marling v. Jones, I38 Wis. 82, IIg N. W. 931 (Ig09), criticized in (Ig09) 57 U. OF PA. L, REv. 662.

${ }^{\circ}$ See Brannan, op. cit. supra note 2 at $163-164$, and authorities there cited.

6249 N. Y. 307, I64 N. E. 108 (1928).

w See summary principles of statutory interpretation involved in this and other decisions of this court. Beutel, op. cit. supra note 23 .

For a general summary of this pressure on legislatures see Beutel, The Pressure of Organized Interests as a Factor in Shaping Legislation (1929) 3 So. CaLIF. L. REv. Io and authorities and statutes there cited. 
ing and passage of Uniform Legislation. The bankers alone are so powerful that the Chairman of the Committee on Amendments was willing to recommend a proposed amendment to section $62-2^{5 \overline{5}}$ on certified checks against his better judgment in order to secure their help in passing the other proposed amendments. ${ }^{56}$

This particular amendment provides that where an instrument has been altered before certification the bank is liable to a subsequent holder in due course only for the original amount. This is not only contrary to the gen- . erally.accepted commercial law of the world and to commercial understanding of certified checks $;^{57}$ but it throws upon subsequent innocent purchasers of certified checks the risk of alteration which they could not possibly discover. The amendment has been suggested because the banks do not want to be liable on their certification for more than they can collect from the drawer. ${ }^{58}$ The result is to discourage the use of certified checks by those who know the law. Instead of asking for certification of checks the sophisticated creditor will ask for bank drafts or cashier's checks, and the bank, of course, will be liable to the holder in due course on these instruments according to their tenor even though they were issued in exchange for altered paper. If then, this amendment is adopted, those who know the law will not use certified checks, and the banks will profit only at the expense of the innocent parties who still rely upon the commercial belief that the bank's certified paper is as good as the bank itself. It is hard to see how the cause of justice or the usefulness of the N.I.L. is to be advanced by amendments which simply become a trap for the uninitiated.

Many others, of the proposed amendments, are open to the charge that they are class legislation. ${ }^{59}$ Whatever may be the public spirited intention

๙ The amendment reads as follows: "2. Such person by accepting or certifying the instrument engages to pay it according to the temor of his acceptance; except that where the instrument has been altered after issue, this engagement extends only ta the order for which the party ordering is answerable to the person required to pay."

"s Program of Nat. Conf. of Comm'rs on Unrform State Laws (I931) 20-21.

${ }^{67}$ Ames, The Doctrine of Price v. Neal (I89I) 4 HARv. L. REv. 297, 306-307.

cs Turner, Revision of the Negotiable Instruments Law (1928) 38 YALE L. J. 25, 29-30.

${ }^{69}$ The following amendments suggested by the committee at the last meeting of the Commissioners on Uniform State Laws, see PROGRAM (I93I) 22 et seq., offer decided economic advantages to the creditor class at the expense of debtor:

Section 3, amending $\S 2$ : "The sum payable is certain . . . although it is to be paid: - . (6) With taxes, insurances or other charges relatize to the instrument, the indebtedness evidenced by it, or the security for it." This would legalize and make negotiable all those instruments which carry as part of the contract burdens and service charges, which may, in a falling market, amount to economic strangulation, and provision throwing all the expense of the transaction on the borrower. See also $\$ 6$ amending $\$ 5$ (5).

Section 4, amending \$ 3: "In the following cases the expression of particular conditions or a summary thereof with reference to a separate writing for a full statement of such conditions shall not render the instrument non-negotiable. (2) Where the instrument is issued and shozen on its face to be issued as one of a series, and conditions are placed in the interests of holders as a group upon enforcement by individual holders." Opens the door to squeezing out minorities, in advance where corporate securities are involved, and makes such rights negotiable. 
of the associations or interests proposing such enactments, if amendments of this nature are allowed to find their way to the law and the public at large becomes cognizant of the fact, the cause of uniform legislation and the value of the Uniform Laws Commission will be irreparably damaged. ${ }^{60}$

\section{Failure to Realize the Difficulty and Effect of Amendments}

Many of the proposed amendments which appear in complete form in law review articles or are submitted to legislative bodies spring from an over-confidence in the possibility of getting them passed and the failure to realize the effect of their adoption. The process of getting amendments through the Commission on Uniform Laws is necessarily a tedious one. Such amendments must be carefully considered by committees, turned over to experts for consideration, be given a hearing before the body itself and then held over another year for consideration. After approval by the Commission there remains the Herculean task of getting the amendment adopted by over fifty legislative bodies. This machinery should not be put in motion whenever anybody gets a bright idea about a new possible improvement. Neither is mere technical improvement sufficient justification, nor is the conviction that the Act would have been improved had it been adopted originally in the amended form. Such amending power should be used only for basic defects involving fundamental and far-reaching changes. All suggestions should be held until their full effect may be realized.

In light of this situation amendments to the Act necessarily cannot be attempted oftener than every twenty-five or fifty years. ${ }^{01}$ The slowness of this process has caused some misguided enthusiasts to rush immediately to legislative bodies which are willing to give a sympathetic ear to their propositions, and a large number of amendments have found their way into the particular state laws simply because of this impatience. ${ }^{62}$ Such amendments are usually ill considered and fail to have the benefit of expert knowledge which is available to the Commission itself. The result, without effecting much improvement, is to destroy uniformity.

Sec. I2, amending $\S 37$, and $\S 14$ repealing $\S 47$, are obviously a concession to collecting banks, giving them much greater rights than under the present act. As suggested below, this should be part of the new bank collection code.

Secs. 16 and 17 , amending $\$ 62$ (see supra note 55 ) and creating a new $\$ 62 \mathrm{~A}$, as shown above, greatly increase the rights of the banks at the expense of holders of the instrument.

Sec. 20, amending $\$ 74$ : "The instrument must be exhibited to the person from whom payment is demanded, . . . and when demanded, the signature, or other signed receipt of the person receiving payment nutst be zuritten on the instrument." Thus materially increasing the rights of paying banks, see McCurdy v. The Society of Savings, 6 Ohio Dec. Rep. 1169 , Note (1882) 26 AlB. I. J. 6I ; CAMIPBELI, CASES ON Negottable INSTRuMENTs (Ig28)

275 ; $c$ s. See Eaton, $o p$. cit. supra note $4 \mathrm{I}$, at 266 , where the author points out the effective opposition to the original act simply on the ground that it had the support of the Bankers' Association.

a See Britton, op. cit. supra note 2, at 832 .

a2 The West Virginia Code of 193 I contains over twenty such amendments, Illinois and many other states have also fallen into this error, see Beutel, op. cit. sipra note 8 , and authorities there cited. 
Even if the Uniform Laws Commission could be induced to approve individual amendments more rapidly, the difficulty of getting them adopted by all the state legislatures is a paramount obstacle which must be considered It should be borne in mind that the idea of establishing uniform laws has not been entirely popular. The attempt at codification was begun only after much propaganda and has not achieved marked success. Other uniform laws have failed of adoption even in the majority of the states. ${ }^{63}$ The Negotiable Instruments Act is the one law which has inspired sufficient confidence and support to be adopted by all of the legislators of this country. Even the Sales Act, carrying with it the prestige of Professor Williston, has not been able to equal its achievement. ${ }^{64}$

The desirability of uniform laws is still being weighed in the balance. Many legislators would consider new amendments to the Negotiable Instruments Act as a sign of weakness not only in that Act but in all uniform laws, and the whole movement for uniform laws might be undermined badly by any hasty attempt at amendment to the N.I.L. In this state of affairs no amendments should be approved by the Commission unless there is a crying need for their adoption and a unanimity of opinion among the authorities as to the form which they should take.

It is extremely important to note in this connection that, in spite of much adverse criticism, the N.I.L. has been very successful. No great need for amendment seems to have arisen; and the amendments that have been suggested, far from receiving unanimous support, have been the center of such a controversy that the committees of the Commission itself have been unable to agree on the form that they should take. ${ }^{65}$

\section{The Crystallization of Commercial Law and Related Acts}

It should be borne in mind also that the law of negotiable instruments under the Act, like the suggested amendments to it, has not yet crystallized in the minds of the profession.

The present members of the Bench and Bar are men educated and grounded in the common law tradition with little experience with codified

${ }^{3}$ An examination of the current edition of Uniform Laws Ammotated will show that of forty-seven statutes approved by the Commission only four have been passed by more than half the states; these are the Uniform Warehouse Receipts Act (48); the Sales Act (30); the Uniform Bills of Lading Act and the Uniform Veterans' Guardianshib Act, each passed by 27 .

os To date the Sales Act has been adopted in only thirty jurisdictions, see I U. L. 9 (I93I) vii.

${ }^{\text {en }}$ See authorities supra note 22 ; cf. also the Williston committee's amendments, HandDOOK, NAT. CONF. of COMM'RS ON UNIFORAr State LAW (I928) I80 et seq. with those of Mr. Llewellyn's committee, Program of.NAT. Conf. OF Comm'Rs oN Uniform State Laws (1931) 22 ct seq. and note that Mr. Llewellyn's committee not only disagrees with the Williston committee, but cannot agree among themselves on some of the most important of their suggested amendments, ibid. I8-21, 26, 28, 3I, 35, 42-53. 
law. For years after the adoption of the Act, in many jurisdictions it was ignored or misunderstood. For example, not until several recent decisions ${ }^{66}$ has there been any apparent understanding of the sections of the Act pertaining to value. Even more serious is the state of mind of the profession on the question of the proper method of interpreting the Act and of applying it to problems in its field. As has been pointed out elsewhere, ${ }^{67}$ there are at least six or seven different and conflicting theories of interpretation now flourishing in this country. In such a situation it is premature to discuss proposed amendments before there is a general understanding as to what is being amended and how the amendments are to be applied. Tampering with the Act under present conditions is likely to lead only to further confusion.

The confusion within the field of the law of negotiable instruments itself is even more marked, and is, to some extent, caused by the state of the law in other closely related subjects. There is a strong movement to settle many moot problems of commercial law by the adoption of carelessly drawn codes. These statutes, aimed at particular situations which their framers hope to remedy at once, are likely to lead to unexpected complications in other fields where the law has already been reduced to writing. This has been apparent in the hasty adoption of the many so-called bank collection codes. ${ }^{68}$ Some of these codes have practically destroyed the effect of the blank endorsement where a bank is the indorsee, and other sections of the same act have greatly altered the effect of restrictive indorsement. ${ }^{69}$ Many related acts of this nature are now being passed both with and without the approval of the Uniform Law Commission. The Uniform Fiduciaries Act and the Uniform Bank Collection Act are examples of related uniform laws aimed at one particular subject which are changing the effect of sections of the Negotiable Instruments Act. ${ }^{70}$

$\omega$ This difficulty was apparent not only in the cases of pre-existing debt as value, see BRANNAN, op. cit. supra note 2 , at $236-246$, but also on the question of bank credits as value. It was only within the last few years that courts began to see that such credit was clearly value under \$25, see Blucher v. National Bank of Baltimore, I5I Md. 5I4, I35 Atl. 383, 49 A. L. R. I366 (I926); Merchants Bank v. Nissen, 46 S. D. I21, I90 N. W. I0I4 (I922); $c f$. cases cited in BranNan, supra at 386 et seq.

or Beutel, op. cit. supra note 8.

cs These codes have been adopted in seventeen states during the last two years. See: Idaho, Laws of I93I, c. 60; Illinois, Laws of I931, p. 67I; Indiana, Acts of 1929, c. 164, p. 5I4; Kentucky, Acts of 1930, c. 13; Maryland, Laws of 1929, c. $454 ;$ Michigan, Public Acts of I931, No. 240; Missonri, Laws of 1929, p. 205; New Jersey, Laws of 1929, c. 270; New Mexico, Stats. of I929 (Courtright) art. 13; Laws of New Jersey, I929, c. 589 ; Oregon, Laws of I93I, c.' 138; Pennisylvania, Act 198 of 1931 ; South Carolina, Acts of 1930, No. 822; Washington, Laws of 1929, c. 203 ; West Virginit, Act of 1931, c. 15; Wisconsin, Stats. of I929, c. 220.15; Wyoming, Sess. Laws of 1931, c. 74 .

${ }^{\infty}$ Sec. 2 of the Pennsylvania Act . . . "where an item is deposited or received for collection, the bank of deposit shall be agent of the depositor for its collection." Act Ig 8 of I93I (the italics are the present writer's). This section prevents the bank from being a holder in due course, which is clearly the law under $\$ \S 25,52$ and 57 . Other portions of the act create totally new rights in regard to the collection and restrictive indorsements, see $\$ \S 4$ to I3.

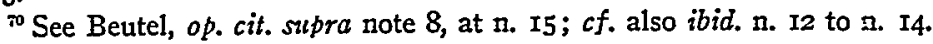


From the point of view of legal theory it is difficult to understand why the collection of negotiable instruments by banks is not properly part of the Negotiable Instruments Law; or why bankers should be governed by rules different from those applied to other similar commercial transactions. But the Commission on Uniform Laws, for practical reasons, seems committed to this policy from which far-reaching results are certain to flow.

The growth of these separate laws covering subsidiary business problems closely related to and, as a matter of law, overlapping the Negotiable Instruments Act is raising an extremely difficult problem which must be faced in the near future. In the light of this movement toward functionalizing the law for various types of business, it seems useless to amend the N.I.L. until there is a crystallization of these new laws, and some definite understanding of the border lines between and the proper fields of the statutes. The interplay of these new codes is bound to cause confusion which must uitimately result in a recodification in which all of these closely related commercial laws are joined in one uniform commercial code.

Foreign commercial codes with totally different requisites of negotiability from our own are also causing some difficulty. Since the United States has suddenly sprung into prominence as the banking center of the world, the increased interchange of foreign paper is creating a problem which finds its solution in a serious movement for the international unification of the law of negotiable instruments. ${ }^{71}$ Any attempt at amendment of the act that overlooks this difficulty seems short-sighted and provincial.

If then, total recodification is certain to become a pressing problem in the near future, it seems almost futile to make amendments to the present Negotiable Instruments Law unless there are major defects in the Act which must be remedied at once.

\section{Are There Any Major Difficulties With the Negotiable Instruments Law?}

One of the major criticisms of the Act has been that it is unnecessarily broad. Unlike the English Act, the codifiers chose to cover the whole field of negotiable paper and have excluded either by necessary inference or direct prohibition the negotiability of paper not coming within the terms of the Act.

a. Rigidity and Negotiability by Contract. This policy has been criticised because it creates rigidity and prevents the growth of new commercial paper. The proposed amendments, mentioned above, ${ }^{72}$ to sections $I$ to 6 are calculated to correct this difficulty by allowing bankers, brokers, merchants, etc., to create their own types of negotiable instruments. It should be noted, however, that the formal requisites of negotiable instruments are necessarily

7 See Uniform Bills of Exchange Law (19I2) 28 BANkING L. J. 382 ; Hudson and Feller, International Unification of Laws Concerning Bills of Exchange (I93I) 44 HARv. L. REV. 333.

${ }_{72}$ See supra note 20. 
arbitrary and a certain amount of rigidity is highly desirable. The Act was adopted to bring about commercial and legal certainty in this respect, so that the maker, payee, indorser, and holder might be assured of his rights by the use of an established form. It would be unfortunate indeed to let down the bars to all kinds of instruments simply because commercial practice has found it desirable to have a few types of paper on the border line of negotiability treated as negotiable. Neither is it entirely clear that a great hardship to business results from excluding from negotiability some of the paper which passes current in the business world. The only advantage of negotiability over non-negotiability is that the purchaser from a thief is protected. Claims of legal and equitable title and defenses may be cut off by estoppel. ${ }^{73}$

Another major problem closely allied to and growing out of this diffculty is the problem of negotiability by contract. Those desiring amendments to the Act have suggested that the parties should be allowed to make any type of instrument that they desire negotiable by mere agreement, but no amendment has yet been forthcoming which would accomplish this result; neither is it clear that negotiability by contract is entirely excluded by the Act especially in light of the analogy offered by section 5 , subsection 3 , which reads as follows:

"But the negotiable character of an instrument otherwise negotiable is not affected by a provision which:

(4) Waives the benefit of any law intended for the advantage or protection of the obligor."

However, the problem of negotiability by contract involves certain major considerations of policy which should not be hastily decided. For example, the small borrower who approaches his banker, broker or loan dealer is not in a condition to contract freely. If negotiability by contract were allowed, either by repeal of the prohibitory sections of the present Act or by some new form of amendment, these small borrowers would be at the mercy of unscrupulous members of the creditor class who could make any sort of contract negotiable by simply inserting a provision to that effect in the printed form. ${ }^{74}$

The present Act draws a very nice line between the type of burdensome subsidiary contract of this nature which will or will not be allowed. ${ }^{75}$ Viewed in this light the sections prohibiting negotiability of instruments

${ }^{7}$ See Contracts Restatement (Am. L. Inst. I928) § I74; Hopple v. Clearland Discount Co., 25 Ohio App. 138, 157 N. E. 414 (1927); Union Trust Co. v. Oberg, 214 N. Y. 517,108 N. E. 809 (I9I5); Goodwin v. Roberts, I A. C. 476 (I876); Note (1924) 33 Y L. J. 302; Kelly v. Universal Oil Supply Co., 65 Cal. App. 493, 224 Pac. 26r (Ig24). Where real commercial difficulties have developed from unique paper, legislatures have been quick to pass remedial statutes. See N. Y. Laws of I926, c. 704, Personal Property Law \$\$ 260262, Note (1926) 12 CoRn. L. Qł 97, Note (1926) 26 CoL. L. Rev. 884; N. Y. Personal Property LAW (1930) art. 8, \$\$260-262, Note (I930) 40 Yale L. J. 26I.

" See the excellent comments on this aspect of our social and legal order by Llewellyn, What Price Contract (I93I) 40 YALE L. J. 704, 73I et seq.

${ }^{\top} C$ f. N. I. L. $\S \S I, 2,3,4,5,6$, I0, 12, 63, 68, I32, I4I, I62. 
containing certain types of promises are meeting a great social need. On the other hand, the loans made by great corporations, municipalities and other businesses having the constant advice of legal experts need no such protection. There is no reason why any sort of promise in a corporate bond should not be made negotiable by contract if it meets commercial convenience, protects innocent purchasers, and if the parties who deal on equal footing so desire. ${ }^{76}$

The negotiability of collateral securities such as mortgages, ${ }^{77}$ pledges, and the like, which has caused a tremendous amount of confusion in the courts, also involves these dual considerations of policy. So also the proposed amendments to sections 2,3 and $5^{78}$ liberalizing the negotiability of instruments containing references to collateral are influenced largely by corporate considerations ${ }^{79}$ and if enacted in the present form they are likely to work great hardships on the individual debtor.

It is submitted that the present Act adopts the proper policy toward the small borrower. The difficulties of the larger corporations can best be corrected by a new corporate securities act which, following the present policy of the Commission, might be recommended as a separate enactment or as Title 5 of the present Negotiable Instruments Law, and so retained until recodification of the entire field of commercial law is undertaken.

${ }^{78}$ It may be that the courts already have drawn this distinction between individual and corporate contracts. Cf. American Nat. Bank v. Sommerville, IgI Cal. 364, 216 Pac. 376 (1923); Enoch v. Brandon, 249 N. Y. 263, I64 N. E. 45 (1928).

"See Brannan, op. cit. supra note 2 , at 489 et seq.

${ }^{78}$ Sec. 2. "The sum payable is a sum certain . . . although it is to be paid: (6) With taxes, insurances or other charges relative to the instrument, the indebtedness evidenced by it, or the security for it." with:

Sec. 3, I. "An unqualified order or promise is unconditional... . though coupled

(c) A statement of, or a reference to a separate zeriting for a statement of, the holder's rights concerning any security for the instrument.

2. In the following cases the expression of particular conditions or a summary thereof with a reference to a separate zuriting for a full statement of such conditions shall not render the instriment non-negotiable:

(a) Where the instrument is issued and shown on its face to be issued as one of a series, and conditions are placed in the interests of the holders as a group upon enforcement by individual holders;

(b) Where the instrument is issued by a government or goiernmental agency and payment is limiled to the proceeds of particular described taxes, assessments or similar sources of revenue;

(c) Where the instrument is issued by an unincorporated business organization, or by the representatives of an estate, and payment is limited to the particular fund constituted by the entire assets of such unincorporated business organization or estate."

Sec. 5. "The negotiable character of an instrument otherwise negotiable is not affected by a provision which:

(5) Contains a promise to do any act or make any payment in addition to the payment of the instrument, even thongh such additional promise be not itself negotiable, provided the additional act or payment promised is apparently intended only to give or maintain security for the payment of the instrument or to secure to the holder the full realization of the payment called for by the instrument free of expenses or taxes." PROGRAM OF NAT. CoNF. OF COMM'RS ON UNIFORM STATE LAWS (I93I) 23-25.

See Professor Chafee's excellent suggestion on this point, BRANNaN, op. cit. supra note 2 , Preface vi. 
b. Difficulties of Collection, Payment and Acceptances. A number of major difficulties of the present Act have been suggested by Professor Chafee, ${ }^{80}$ the most important of which deal with problems in the field of banking. There is considerable difficulty arising out of the collection of instruments under restrictive indorsements ${ }^{\text {s1 }}$ the nature of an indorsement "for deposit", "pay to any bank or banker", etc., and the duties of the collecting banks thereunder. ${ }^{82}$

A partial solution of these problems has already been attempted by bank collection codes in the various states and it seems that the entire subject should be covered in the new Uniform Bank Collection Code. ${ }^{83}$ So also the questions of the right of the collecting bank to send an instrument direct to the drawee, the liability of a paying bank for holding paper beyond the specified time and payment under mistake; ninety per cent. or more of these problems arise in the banking business, and as a matter of legal analysis all fall as much in the field of bank collections as they do in the subject of negotiable instruments. Since the Commission is now attempting to frame a new bank collection code it would be much better to solve all these problems in that code and leave the Negotiable Instruments Act as it is where non-banking problems are affected.

\section{Conclusion}

It is perhaps unfortunate that all of these problems cannot be solved at once and reduced to one unified code. But, as long as we are committed to the theory of partial codification, minor amendments in the present Act should not be attempted when, as a practical matter, they can be solved as well in new and related acts. As soon as the whole field of commercial law, and commercial paper in particular, has become so crystallized that the statutes can be brought together in a uniform commercial code, all should be thoroughly revised. At the present time the practical dangers that amendments may result in further conflict in theories of interpretation, unsatisfactory decisions and in discredit of the entire movement for uniform law, far outweigh any theoretical advantages that may be gained from sporadic changes. For these reasons it is submitted that the Negotiable Instruments Law should not be amended until greater defects appear or until complete recodification becomes necessary.

80 See ibid. $\mathrm{v}$ to vii.

in It has been objected that under the wording of $\$ 37$ a trustee to whom an instrument has been indorsed in trust cannot be a holder in due course, see ibid. 314 , 319 et seq.; but see Atlantic City Nat. Bank v. Commercial Lumber Co., I55 Atl. 762 (N. J. I93I) where a contrary result was achieved under the act. It seems also that this interpretation can be reached when $\$ \$ 36,37,47$ and IgI are read together without doing damage to the present verbiage of those sections. At any rate the case is not of sufficient importance or frequency to warrant a separate amendment to the act.

$\approx$ The fact that bank collection codes have been passed in seventeen states in the last three years, see sitpra note 68 , is conclusive evidence of the great commercial unrest in this field.

See Program of Nat. Conf. of Comm'rs on Uniform State Laws (i93i) 57 to 8I. 